\title{
Elaboration and validation of an e-book with the laws about diabetes in schools
}

\author{
Elaboração e validação de um e-book com as leis sobre o diabetes nas escolas \\ Elaboración y validación de un libro electrónico de las leyes sobre la diabetes en las escuelas
}

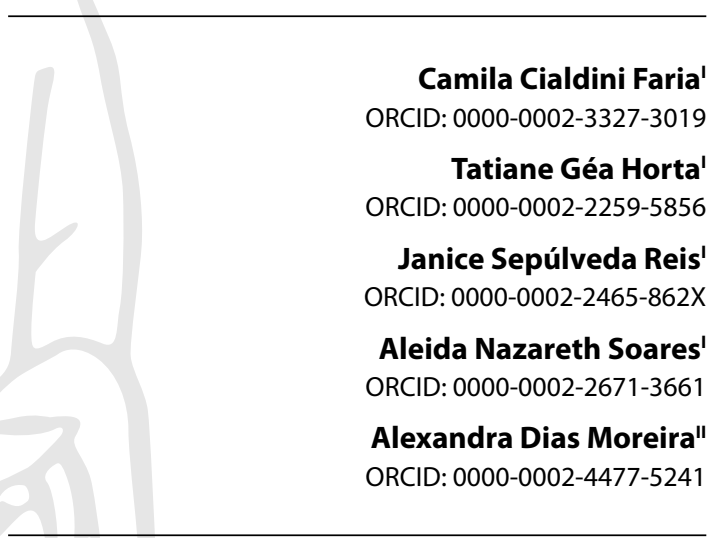

'Instituto de Ensino e Pesquisa da Santa Casa de Belo Horizonte.

Belo Horizonte, Minas Gerais, Brazil.

"Universidade Federal de Minas Gerais. Belo Horizonte, Minas Gerais, Brazil.

How to cite this article:

Faria CC, Géa-Horta T, Reis JS, Soares AN, Moreira AD. Elaboration and validation of an e-book with the laws about diabetes in schools Rev Bras Enferm. 2022;75(3):e20200711. https://doi.org/10.1590/0034-7167-2020-0711

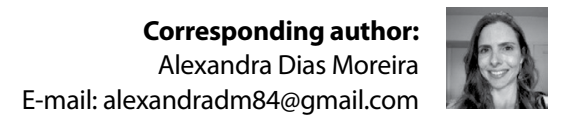

EDITOR IN CHIEF: Dulce Barbosa ASSOCIATE EDITOR: Maria Isabel Salamanca

Submission: $07-27-2020$

Approval: 07-19-2021

\begin{abstract}
Objectives: to elaborate an e-book about children and adolescents' rights and duties concerning diabetes in schools. Methods: we developed this methodological study in nine steps: Creation process definition, bibliographic survey, e-book elaboration, readability and apprehensibility examination, illustration, committee of judges and targeted audience validation (students' moms with diabetes and school staff), experts' meetings and final discussion. We have considered acceptable the Content Validity Coefficient minimum of 0.80 . Results: we obtained an average Content Validity Coefficient of 0,97 for clarity and relevance, and the images had $94 \%$ approval. In the face-to-face test, the targeted audience have considered the material clear and adequate to the intended purpose. Conclusions: the $e-b o o k$ was elaborated and validated regarding the content and relevance, and may be used to instruct the population about diabetes' laws in schools.
\end{abstract}

Descriptors: Teaching Materials; Diabetes Mellitus; Validation Study; Child; Legislation as Subject.

\section{RESUMO}

Objetivos: elaborar e validar um e-book sobre os direitos e deveres de crianças e adolescentes com diabetes nas escolas. Métodos: estudo metodológico, desenvolvido em nove etapas: definição do processo de criação, levantamento bibliográfico, elaboração do e-book, cálculo da legibilidade e apreensibilidade, ilustração, validação pelo comitê de juízes e público-alvo (mães de alunos com diabetes e equipe escolar), reuniões de especialistas e discussão final. Considerou-se aceitável o Coeficiente de Validade de Conteúdo mínimo de 0,80. Resultados: obteve-se o Coeficiente de Validade de Conteúdo médio de 0,97 para clareza e relevância, e as imagens tiveram $94 \%$ de aprovação. No teste face a face, o público-alvo considerou o material claro e adequado à finalidade proposta. Conclusões: o e-book foi elaborado e validado quanto a conteúdo e relevância, podendo ser utilizado para instruir a população acerca das leis sobre o diabetes nas escolas.

Descritores: Materiais de Ensino; Diabetes Mellitus; Estudo de Validação; Criança; Legislação como Assunto.

\section{RESUMEN}

Objetivos: elaborar y validar un libro electrónico sobre los derechos y deberes de niños y adolescentes con diabetes en las escuelas. Métodos: es un estudio metodológico desarrollado en nueve etapas: definición del proceso de creación, levantamiento bibliográfico, elaboración del libro digital, cálculo de la legibilidad y percepción, ilustración, validación por el comité de jueces y público objeto (madres de alumnos con diabetes y equipo escolar), reuniones de especialistas y discusión final. Se consideró aceptable el Coeficiente de Validez de Contenido mínimo de 0,80. Resultados: se obtuvo el Coeficiente de Validez de Contenido promedio de 0,97 para claridad y relevancia y las imágenes obtuvieron un $94 \%$ de aprobación. En la prueba presencial, el público objeto consideró el material claro y adecuado para la finalidad propuesta. Conclusiones: el libro electrónico fue elaborado y validado según contenido y relevancia, pudiendo utilizarse para instruir a la población sobre las leyes de la diabetes en las escuelas. Descriptores: Materiales Didácticos; Diabetes Mellitus; Estudio de Validación; Niños; Legislación como Asunto. 


\section{INTRODUCTION}

Diabetes Mellitus (DM) is a chronic disease that involves a group of metabolic disorders characterized by a hyperglycemic state, caused by the alteration of secretion and/or disorders in the insulin action that, according to the etiology, will subsidize the type of diabetes classification ${ }^{(1-2)}$.

We estimate the existence of more than half of a million children and adolescents under 15 years old with the type 1 Diabetes Mellitus (DM1) diagnosis in the world. According to the International Diabetes Federation - IDF (2017), when an estimator involves children and adolescents till 20 years old, the number increases to more than 1 million, with the incidence increasing around 3\% a year. Besides, there is evidence that type 2 Diabetes Mellitus (DM2) cases are increasing among children and adolescents because of obesity and sedentarism ${ }^{(3)}$.

Diabetes treatment management is different among adult and patients who are children, even for an identical stage of insulin therapy. Aspects regarding sexual maturation and the growth in this age group change the physiopathology of the disease ${ }^{(4)}$.Thus, children and adolescents' routine with DM1 is full of peculiarities. Throughout the day, frequent glycemic monitoring and multiple insulin applications are carried out ${ }^{(2)}$. The feeding requires extra care, demanding higher caution regarding the hypoglycemia risks, and physical activities must be stimulated and monitored ${ }^{(2)}$.

The adequate control of diabetes involves complex aspects, and in schools, the students' management must involve teachers, and other staff, besides parents and guardians, aiming to create a safe environment for kids with diabetes ${ }^{(5)}$. Hence, it is important that educators and other employees maintain effective communication with families and receive training so that students with specific needs and conditions are properly assisted ${ }^{(6)}$.

According to the American Diabetes Association recommendation, school staff can and must shelter students with diabetes once that the students are constantly under their supervision ${ }^{(7)}$. The school became an important help and support environment, which grants the institution big responsibility associated with the challenge of adequate attention and care to the children and adolescents ${ }^{(4)}$.

Children may present difficulties in managing their treatment according to the level of complexity in each step, therefore, schools must provide effective training to educators to monitor children with chronic conditions. Adequate monitoring must be carried out during all school periods, however, most of the time the staff team does not have the minimum knowledge to deal with diabetes management because of the lack of training and necessary information ${ }^{(6,8-9)}$, which may be addressed in educational materials, such as booklets and e-books elaborated specifically to this public.

Thus, the main restraining criteria of monitoring involve the lack of knowledge of the scholar team because of insufficient orientations, the inadequate offer of the school meal, prejudice, and, finally, the embarrassment experienced by many students. Therefore, it is indispensable a higher approximation between the family-school-students communication, recognizing their rights and duties. The lack of clear and objective legislation or low applicability of the law in practice may turn diabetes management in schools inappropriate.

\section{OBJECTIVES}

To elaborate an e-book about children and adolescents' rights and duties with diabetes in schools.

\section{METHODS}

\section{Ethical Aspects}

The research was carried out following all orientations under the resolution $n^{\circ} 466 / 2012$ of the National Health Council, which approves the guidelines and regulatory standards for researchers involving human beings ${ }^{(10)}$. We submitted to the Research Ethics Committee (CEP) of the Instituto de Ensino e Pesquisa da Santa Casa $\mathrm{BH}$. We registered the judges' agreement in freely participating in the study in the initial menu of the e-surv platform. The participants signed the Consent Form (TCLE).

\section{Design and study period}

This methodological study was carried out from October 2016 to May 2018 and developed in nine steps (Chart 1).

Chart 1 - E-book development steps, Belo Horizonte, Minas Gerais, Brazil, 2018

\begin{tabular}{|c|c|}
\hline Steps & Steps description \\
\hline $\begin{array}{l}1^{\text {st }} \text { Step: Definition } \\
\text { of the items related } \\
\text { to the creation } \\
\text { process. }\end{array}$ & $\begin{array}{l}\text { - Identification of targeted audience; } \\
\text { - } \quad \text { Definition of the material objective; } \\
\text { Brazilian legislation regarding the rights and } \\
\text { duties of children and adolescents. }\end{array}$ \\
\hline $\begin{array}{l}2^{\text {nd }} \text { Step: } \\
\text { Elaboration of the. }\end{array}$ & $\begin{array}{l}\text { We elaborated the e-book content through the } \\
\text { Brazilian legislation survey: Federal Constitution } \\
1988^{(11)} \text {, Statute for Children and Adolescents }{ }^{(12)} \text {, } \\
\text { Law of Directives and Bases of National } \\
\text { Education }{ }^{(13)} \text {, Consumer Code, and directives of } \\
\text { the main diabetes associations (ADA, SBD) }{ }^{(14)} \text {. }\end{array}$ \\
\hline $\begin{array}{l}3^{\text {rd }} \text { Step: } \\
\text { Determination of } \\
\text { readability and } \\
\text { apprehensibility. }\end{array}$ & $\begin{array}{l}\text { - Calculation and analysis of the formula results: } \\
\text { Flesch Reading Ease, Flesch Kincaid, and } \\
\text { Coleman Liau index. }\end{array}$ \\
\hline $\begin{array}{l}4^{\text {th }} \text { Step: Illustration } \\
\text { and layout. }\end{array}$ & $\begin{array}{l}\text { We created the illustrations especially for } \\
\text { the e-book through a graphic designer, } \\
\text { which utilized the Corel Draw }{ }^{*} \mathrm{X} 8 \text { and Adobe } \\
\text { llustrador program. For the layout, we utilized } \\
\text { the PowerPoint Microsoft } 2016 \text {. }\end{array}$ \\
\hline $\begin{array}{l}5^{\text {th }} \text { Step: Meeting } \\
\text { with the experts } \\
\text { committee. }\end{array}$ & $\begin{array}{l}\text { - Correction and adjustments for better } \\
\text { comprehension, respecting the Flesch Reading } \\
\text { Ease, Flesch Kincaid, and Coleman Liau index } \\
\text { calculation. } \\
\text { - Content and graphic art approval. }\end{array}$ \\
\hline $\begin{array}{l}6^{\text {th }} \text { Step: Material } \\
\text { evaluation by the } \\
\text { judge committee. }\end{array}$ & $\begin{array}{l}\text { Validation of the e-book by the committee of } \\
\text { judges through the e-surv, an online platform. } \\
\text { Content Validity Coefficient calculation and } \\
\text { analysis. }\end{array}$ \\
\hline $\begin{array}{l}7^{\text {th }} \text { Step: Meeting } \\
\text { with the experts } \\
\text { committee. }\end{array}$ & $\begin{array}{l}\text { Discussion among experts to evaluate the } \\
\text { suggestions given by the judges and pertinent } \\
\text { changes on the e-book. }\end{array}$ \\
\hline $\begin{array}{l}8^{\text {th }} \text { Step: Validation } \\
\text { of the material } \\
\text { by the targeted } \\
\text { audience. }\end{array}$ & $\begin{array}{l}\text { - Face-to-face test with the targeted audience } \\
\text { aiming to evaluate the clarity, relevance and } \\
\text { utility of the content. } \\
\text { - Evaluation of material images. }\end{array}$ \\
\hline
\end{tabular}

To be continue 
Chart 1 (concluded)

\begin{tabular}{|l|l|}
\hline Steps & Steps description \\
\hline $\begin{array}{l}9^{\text {th }} \text { Step: Final } \\
\text { discussion } \\
\text { among experts } \\
\text { committee. }\end{array}$ & $\begin{array}{l}\text { Final discussion among experts to evaluate } \\
\text { the suggestions of the targeted audience and } \\
\text { pertinent changes. }\end{array}$ \\
\hline
\end{tabular}

\section{Study sample}

Following the literature recommendation for the validation process, to form a committee of judges, it is necessary a number from six to twenty participants, and preferably it must be an odd number to avoid opinion ties ${ }^{(15)}$. To catalog the potential judges, we carried out consultations in the Lattes Platform of the National Council of Scientific and Technological Development (CNPq). The inclusion criteria were: health professionals (medicine, nursing, and nutrition) with experience in diabetes and post-graduation at the level of specialization, master's or doctorate degree, applied linguistics professionals, and professionals who graduated in pedagogy, preferably with experience in educational materials validation. The inclusion of lawyers to the committee of judges occurred randomly with a single criterion of experience in healthcare law.

We selected seventeen professionals from different practice areas, and we have sent, through email, an invitation to participate as an appraising judge, with orientations about the process of evaluation, a link to access the questionnaire at e-surv, and the e-book in PDF. Nine judges participated in the evaluation from December 2017 to January 2018.

For the e-book validation by the targeted audience, we invited five mothers of students with diabetes and five school employees from private and public middle schools situated at Belo Horizonte.

\section{E-book elaboration}

Initially, we proceeded to search for the Health Ministry's main publications about diabetes in schools and at the electronic database LILACS and Pubmed/MEDLINE. We utilized the following Health Sciences Descriptors (DeCS): Validations Studies, Teaching Materials, Diabetes Mellitus, Children, Adolescents, and Health Legislation. Through the consulted literature, we wrote the first version of the e-book content, and, next, we calculated the apprehensibility and readability formula(16), essential factors for the content to achieve the proposal to educate different audiences.

We utilized the Flesch Reading Ease (FRE) ${ }^{(17)}$, Flesch Kincaid Readability index $(\mathrm{FK})^{(18)}$, and Coleman Liau Index $(\mathrm{CL})^{(19)}$ formulas to evaluate the comprehension index of the written message. The readability expression refers to the size, type, and color of the letter, the paragraph space and alignment, and the text formatting elements. On the other hand, the term apprehensibility refers to the ease of readability, comprehension, reading speed, and text apprehension, factors that are related to the writing form and vocabulary used ${ }^{(20-21)}$.

To calculate the Flesch Reading Ease, we utilized the average number of syllables per word and the average sentence length, in the formula: FRE = 206.835 - (1.015 x CMF) - (84.6 x MSP), in which CMF is the average size of a phrase and MSP the average number of syllables per word. The obtained result of the formula may vary from 0 to $100 \%$. The 0 value indicates low readability and 100 high readability ${ }^{(17)}$. For this study, we pre-determined that the phrases should obtain values superior from $50 \%$, indicating a standardizing level reading ease to very easy, that is, it is necessary a minimum education level from the fourth grade ${ }^{(16)}$.

The Flesch Kincaid Readability index is calculated by the formula: $\mathrm{FK}=([0.39 \times \mathrm{CMF}]+[11.8 \times \mathrm{MSP}])-15.59$. The calculation converts the apprehensability in years of education, in other words, the result suggests the necessary number of years to adequately understand the content. The value of the results varies from 0 to 35, in which the values close to 0 indicate the necessity of low educational level and values between 30 to 35 indicate the necessity of high educational level for comprehension. Following the aim of the study, we needed to obtain values closer to 0 , referring to the minimum necessity of 6 years old of educational level to comprehend the message ${ }^{(16,18)}$.

The Coleman Liau Index determines the apprehensability of the content. The level of education is found through the average of the sentence length and the average of the number of characters per word. For the calculation, we utilized the following formula: $\mathrm{CL}=(5.89 \times \mathrm{MNP})-0.3 \times(1 / \mathrm{CMF})-15.8$, in which $M N P$ is the average of numeric characters per word ${ }^{(19)}$. We considered the result adequate when the written text is comprehended by readers with educational level from 4th grade till university level, with a minimum of 6 years of education ${ }^{(16,19)}$.

To determine and evaluate the formula values of readability and apprehensability, the number of words, characters, and sentences of the text was determined by the word-counting tool from Microsoft ${ }^{\circledR}$ Word 2017. Regarding the number of words characters, we considered the value without space. We obtained the number of syllables by the online counter Separar em silaba, available at: http://www.separarensilabas.com/index-pt.php; We calculated the average sentence length (CMF) and the average number of syllables per word (MSP) manually, dividing the number of words by the number of sentences, and the number of syllables by the number of words, respectively ${ }^{(16,21)}$.

After the adaptation of the e-book regarding the readability and reprehensibility, we carried out a meeting among experts to evaluate the content and, if necessary, carry out relevant modifications to the material. The committee of experts was composed of an endocrinologist, three nurses, and two nutritionists that defined the preliminary version of the e-book.

Next, we submitted the material through the online platform e-surv (esurv.org) to the evaluation and qualification by the committee of judges. At this step, the material is evaluated by its relevance and clarity, aiming to standardise the content to better outreach the targeted audience ${ }^{(20)}$.

\section{Booklet validation by the committee of judges}

The judges evaluated the sentences of the e-book regarding the clarity and relevance, assigning a score of 1 to 4 stars, in which: 1 star - the need for complete reformulation; 2 stars - the need for partial reformulation with many changes; 3 stars - the need for partial reformulation with optional changes to improve the content; 4 stars - no need for reformulation. When the sentences were evaluated with 1 or 2 stars, we requested that they left comments for the adaptation or correction of the content. In the case of a 3 stars evaluation, we requested that they comment on improvement 
suggestions. In the end, for the judges that have finished the evaluation, we sent a "thank you" email with a certificate.

As well as the written message, we requested the evaluation of the images of the e-book according to its adequacy to the text. After the validation of the judges, and with the level of agreement calculated, we carried out a new meeting among experts to evaluate the pertinent suggestions and carry out changes in the e-book.

\section{Booklet validation by the targeted audience}

We carried out the face-to-face test with the sample of the targeted audience, characterized by parents and/or guardians of children with diabetes, in school age, besides professionals that work in public or private middle schools from Belo Horizonte, Minas Gerais. The targeted audience was composed of ten participants: five mothers of students with diabetes and five professionals of the school staff, in this case, four teachers and a school nurse from a private school. For the parent group, we applied additional criteria of having an educational level of minimum 6-year or 4th grade complete.

We presented the e-book to the public through an Ipad Apple. For the material evaluation, the researcher with the participants read the e-book page by page. We requested that they evaluate language and image clarity, if the content was relevant, ease comprehension or if there was any improvement suggestion to facilitate the comprehension. We recorded the entire process with the audio tool of a cell phone for the full-text transcription. After the end of the evaluations of the targeted audience, we carried out a new meeting with the committee of experts to evaluate the suggestions and necessary changes to obtain the final version of the e-book.

\section{Result analysis and statistic}

We calculated the level of agreement of the judges by the Content Validity Coefficient (CVC). We calculate the coefficient for each item (CVCi) by the average division of the judges' judgment values ( $\Sigma x j)$ by the maximum value of the last category of the Likert scale (Vmax) for an x-determined item. The total CVC of the scale (CVCt) is given by the subtraction of the judges' CVC (CVCj) for the scale as a whole by the Standard Error (Pej) of the judges' polarization. The CVCj is the division of the total average of the scores (attributed to every item in the scale) by the scale's maximum value. On the other hand, Pej is calculated by the ratio between 1 and the absolute number of the judges $(\mathrm{Nj})$ to the power of the absolute number of the judges. The analysis result will determine the level of agreement of the judges regarding the evaluated items. The higher the CVC, the lower is the necessity of changing and improving the text style $\mathrm{e}^{(22)}$.

\section{RESULTS}

\section{E-book elaboration}

The final version of the e-book has a total of 25 pages with the title "Diabetes in school: understand the laws about the theme". We divided the material into two blocks with the following themes: 1- school rights and duties; 2 - students with diabetes rights and duties. The e-book contains 16 graphic illustrations designed exclusively by a designer, and its colors are standardized in blue and white. The version also received a positive evaluation of the targeted audience and the committee of experts.

The educational content refers to the Brazilian legislation directed to children and adolescents and to diabetes, which must be known by parents or guardians of students with diabetes and by the professionals of the school staff. Aiming to enrich the content, improve the general readability and apprehensibility of the e-book, and provide to the targeted audience the opportunity to go further in detail of the theme, we add to the end of each page blue highlighted links that provide full access to each law.

The final version of the educational material is available in the following link: https://www.diabetes.org.br/profissionais/ images/Leis_e_as_escolas_final-_2019.pdf.

\section{Characterization of the judges}

Regarding the characteristics of the judges one lawyer, one nurse, one linguist, three physicians, two nutritionists, and pedagogue), we observed that the majority was female (66.67\%), from 30 to 40 years $(55.56 \%)$ and with experience as judges in other studies (66.67\%) (Table 1).

Table 1 - Committee of judges characterization, Belo Horizonte, Minas Gerais, Brazil, 2018

\begin{tabular}{|c|c|c|}
\hline Judges & $\mathbf{n}$ & $\%$ \\
\hline \multicolumn{3}{|l|}{ Sex } \\
\hline Female & 6 & 66.67 \\
\hline Male & 3 & 33.33 \\
\hline \multicolumn{3}{|l|}{ Age } \\
\hline Till 30 years old & 2 & 22.22 \\
\hline 30 to 40 years old & 5 & 55.56 \\
\hline 40 years old or older & 2 & 22.22 \\
\hline \multicolumn{3}{|l|}{ Education level } \\
\hline Undergraduate Complete & 1 & 11.11 \\
\hline Post-graduation / Specialization & 1 & 11.11 \\
\hline Master's degree on course & 1 & 11.11 \\
\hline Completed master's & 4 & 44.45 \\
\hline Doctorate's on course & 1 & 11.11 \\
\hline Completed doctorate & 1 & 11.11 \\
\hline \multicolumn{3}{|l|}{ Profession } \\
\hline Layer & 1 & 11.11 \\
\hline Nurse & 1 & 11.11 \\
\hline Linguist & 1 & 11.11 \\
\hline Physician (endocrinologist) & 1 & 11.11 \\
\hline Physician (other specialities) & 2 & 22.22 \\
\hline Nutritionist & 2 & 22.23 \\
\hline Pedagogue (college graduated) & 1 & 11.11 \\
\hline \multicolumn{3}{|l|}{ Time of graduation } \\
\hline$\leq 05$ years & 2 & 22.22 \\
\hline$>05$ years and $\leq 10$ years & 3 & 33.34 \\
\hline$>10$ years and $\leq 20$ years & 3 & 33.33 \\
\hline More than 20 years & 1 & 11.11 \\
\hline \multicolumn{3}{|l|}{ Practice area } \\
\hline Outpatient care & 3 & 33.33 \\
\hline Clinic & 3 & 33.34 \\
\hline Primary health care & 1 & 11.11 \\
\hline School & 1 & 11.11 \\
\hline Scientific research & 1 & 11.11 \\
\hline \multicolumn{3}{|c|}{$\begin{array}{l}\text { Do you hold or are attending a master's degree in } \\
\text { diabetes education? }\end{array}$} \\
\hline Yes & 5 & 55.56 \\
\hline No & 4 & 44.44 \\
\hline \multicolumn{3}{|c|}{$\begin{array}{l}\text { Have you already participated in a committee of } \\
\text { judges for the evaluation of educational materials? }\end{array}$} \\
\hline Yes & 3 & 33.33 \\
\hline No & 6 & 66.67 \\
\hline
\end{tabular}




\section{Booklet validation by the committee of judges}

The result from the e-book content validation by the committee of judges had as an overall result of the pages the CVC of 0.95 for clarity and CVC of 0.99 for relevance. For the entire material, the average CVC of 0.97 and polarization standard error of 0.000000002581 , which implies a high index of agreement between the judges (Table 2).

Table 2 - Content validity coefficient calculated by page after the Judges Committee evaluation, Belo Horizonte, Minas Gerais, Brazil, 2018

\begin{tabular}{ccc}
\hline Item & CVC $_{\mathbf{i} \text { - }}$ Clarity & CVC $_{\mathbf{i}-\text { Relevance }}$ \\
\hline Cover & 1.00 & 1.00 \\
Presentation & 0.97 & 1.00 \\
Page 6 & 0.93 & 0.96 \\
Page 7 & 0.97 & 1.00 \\
Page 8 & 0.86 & 0.97 \\
Page 9 & 0.92 & 0.94 \\
Page 10 & 0.94 & 1.00 \\
Page 11 & 0.83 & 0.97 \\
Page 13 & 1.00 & 1.00 \\
Page 14 & 0.90 & 0.99 \\
Page 15 & 0.94 & 0.99 \\
Page 16 & 1.00 & 1.00 \\
Page 17 & 1.00 & 1.00 \\
Page 18 & 1.00 & 1.00 \\
Page 19 & 0.97 & 0.97 \\
Total CVC & 0.95 & 0.99 \\
Average CVC & & \\
\hline CVC - content validity coefficient for each item. &
\end{tabular}

Table 3 - Suggestions of the judges committee, Belo Horizonte, Minas Gerais, Brazil, 2018

\begin{tabular}{|c|c|c|c|}
\hline \multirow[t]{2}{*}{ Item } & \multirow[t]{2}{*}{ Judges' suggestions } & \multicolumn{2}{|c|}{ Accepted } \\
\hline & & Yes & No \\
\hline Cover & $\begin{array}{l}\text { Add images that correspond to diabetes in the } \\
\text { cover. }\end{array}$ & $\mathrm{x}$ & \\
\hline \multirow[t]{2}{*}{ Page 6} & $\begin{array}{l}\text { Remove the word "all", as the expression } \\
\text { generates redundancy. }\end{array}$ & $\mathrm{x}$ & \\
\hline & Remove the term crime from the affirmation. & $\mathrm{x}$ & \\
\hline Page 7 & $\begin{array}{l}\text { Add the word "staff" for the better understanding } \\
\text { of the subject that must be protected }\end{array}$ & & $x$ \\
\hline Page 8 & $\begin{array}{l}\text { Change the expression "in what is allowed" to } \\
\text { "in what is possible" and "If is not possible" to } \\
\text { "otherwise." }\end{array}$ & $\mathrm{x}$ & \\
\hline Page 9 & $\begin{array}{l}\text { Highlight the word "no" in capital letters, } \\
\text { reinforcing and bold. }\end{array}$ & $x$ & \\
\hline Page 10 & $\begin{array}{l}\text { Use the word "obligation" instead of "duty" } \\
\text { Change the term 'do not/does not have the } \\
\text { duty" to "should have" }\end{array}$ & & $\begin{array}{l}\mathrm{X} \\
\mathrm{X}\end{array}$ \\
\hline Page 11 & $\begin{array}{l}\text { Change the period punctuation to comma in the } \\
\text { initial phrase. }\end{array}$ & $\mathrm{x}$ & \\
\hline \multirow[t]{2}{*}{ Page 14} & $\begin{array}{l}\text { Substitution of the period to comma uniting the } \\
\text { two clauses. }\end{array}$ & $x$ & \\
\hline & Change the term "in condition" to "in conditions." & $\mathrm{X}$ & \\
\hline \multirow[t]{2}{*}{ Page 15} & Substitute the word "give" to "offer." & $\mathrm{x}$ & \\
\hline & $\begin{array}{l}\text { The use of "and" is unnecessary and should be } \\
\text { removed. }\end{array}$ & $\mathrm{x}$ & \\
\hline \multirow[t]{2}{*}{ Page 16} & Explain what would be the term "Kit." & $\mathrm{x}$ & \\
\hline & $\begin{array}{l}\text { Add the word "food" to better describe the term } \\
\text { "source of sugar." }\end{array}$ & $x$ & \\
\hline
\end{tabular}

Suggestions regarding the substitution or addition of words, the judges (Table 3 ) carried out the linguistic and orthographic correction, and the standardization of the images.

Regarding the presentation text and the $05,12,13,16,17,18$, and 19 pages not cited in Table 3, there was no improvement or correction suggestions by the judges.

The experts did not accept some of the suggestions of the committee of judges such as, on page 7, to add "staff." Similarly, the suggestions on page 10 were accepted once that the law does not refer to an obligation to have a health professional at school, allowing the institution to choose whether to have it or not.

In this version, we illustrated the e-book with images from free databases available on the internet. Although the majority of the judges evaluated the images positively, as easy understanding and in complement to the text, there were a few suggestions to standardize features and colors to uniform the layout. Accepted by the experts, we applied the suggestion to the material. We substituted the old images with drawn illustrations by a graphic designer.

\section{Characterization of the targeted audience}

Concerning the characterization of the targeted audience, $100 \%$ of the sample were female, with $50 \%$ being mothers of students with diabetes and $50 \%$ of school professionals. Regarding the age, $10 \%$ is around 20 to 30 years old, $70 \%$ from 30 to 40 years old and $20 \%$ older than 40 years old. About the education level, $10 \%$ completed middle school, $10 \%$ with incomplete high school, $20 \%$ completed high school, $20 \%$ completed higher education, and $40 \%$ have a postgraduate degree or are experts. In terms of profession, the participants were pedagogues (with a college degree) $(30 \%)$, school nurse (10\%), nutritionist (10\%), linguist $(10 \%)$, seamstress $(10 \%)$, and hairdressers $(30 \%)$.

\section{Booklet validation by the targeted audience}

The Table 4 describes the suggestions made by the targeted audience regarding each page of the e-book.

Pages 5, 12, 13, 14, 15, and 19 did not receive suggestions from the targeted audience. Regarding the material as a whole, $100 \%$ of the participants approved the layout and the design, complimented the idea of the links to access the laws, and assured that the e-book would be really helpful for the targeted audience.

\section{DISCUSSION}

Through this methodological study, we have elaborated, validated, and culturally adapted an educational e-book to improve the communication between parents of students with diabetes and educational institutions. Educational materials, when elaborated by experts of the field on a scientific basis, contributes to a better understanding of the diseases and their treatments, being attractive and useful to the targeted audience ${ }^{(23)}$.

In Brazil, the existing politics are distinct and less standardized. Currently, the Federal Constitution of $1988^{(11)}$, the Law of Directives and Bases of National Education ${ }^{(13)}$, the Statute for Children and Adolescents ${ }^{(12)}$, the Civil Code ${ }^{(24)}$, Consumer Code ${ }^{(14)}$, and Penal Code $^{(25)}$ are utilized as basis and support to the diabetes theme 
Table 4 - Suggestions about the e-book by the target audience, parents or guardians of students with diabetes, and school staff members, Belo Horizonte, Minas Gerais, Brazil, 2018

\begin{tabular}{|c|c|c|c|c|}
\hline \multirow[b]{2}{*}{ Item } & \multirow{2}{*}{ Targeted audience suggestion } & \multicolumn{2}{|c|}{ Accepted } & \multirow{2}{*}{ Change } \\
\hline & & Yes & No & \\
\hline Cover & $\begin{array}{l}\text { They did not assimilate the hammer to the laws } \\
\text { - They suggested a more playful illustration for the child. }\end{array}$ & $\mathrm{X}$ & $\mathrm{x}$ & $\begin{array}{l}\text { - Creation of a new cover } \\
\text { - Remove the hammer. } \\
\text { - It is not relevant to the theme. }\end{array}$ \\
\hline Presentation & - Highlight the explanation about the links of the laws. & $x$ & & $\begin{array}{l}\text { - We highlighted the sentence of the links with the } \\
\text { blue color }\end{array}$ \\
\hline Page 6 & - Add a wheelchair user to the drawing of the students. & & $x$ & - It is not relevant to the theme. \\
\hline Page 7 & - Add a law referring to the student, besides the school. & & $x$ & - The theme will be addressed throughout the e-book \\
\hline Page 8 & $\begin{array}{l}\text { - Add the emergency number (SAMU). } \\
\text { - Reinforce the message that the school must contact the family. }\end{array}$ & & $\begin{array}{l}X \\
X\end{array}$ & $\begin{array}{l}\text { - The number is not standardized in brazilian studies. } \\
\text { - The school's responsibility is to help the student. }\end{array}$ \\
\hline Page 9 & $\begin{array}{l}\text { - Although it is not the duty of the school, we can suggest that } \\
\text { the school must learn to measure blood glucose. }\end{array}$ & & $x$ & - It is not the school's duty, as the law says. \\
\hline Page 10 & - Change the drawing to reflect less of a hospital or infirmary. & $\mathrm{x}$ & & $\begin{array}{l}\text { - Develop a new drawing that refers more to the } \\
\text { school environment }\end{array}$ \\
\hline Page 11 & $\begin{array}{l}\text { - Although they understand that the image is about the } \\
\text { medical prescription, they did not relate it to the insulin. }\end{array}$ & $x$ & & $\begin{array}{l}\text { - Add insulin to the recipe. } \\
\text { - We added the word "physician" to better } \\
\text { characterize the recipe }\end{array}$ \\
\hline Page 16 & $\begin{array}{l}\text { - The school must certify the presence of prescription. } \\
\text { - Add the syringe to the drawing. }\end{array}$ & $\mathrm{x}$ & $\mathrm{x}$ & $\begin{array}{l}\text { - It is the subject of the next page. } \\
\text { - Add the syringe as a form of treatment. } \\
\text { - Remove the red cross from the suitcase and replace } \\
\text { it with "Diabetes Kit". }\end{array}$ \\
\hline \multirow[t]{2}{*}{ Page 17} & $\begin{array}{l}\text { - Reinforce that the school must have this private place for } \\
\text { the student. }\end{array}$ & & $x$ & $\begin{array}{l}\text { - We considered the suggestion redundant to the } \\
\text { content. }\end{array}$ \\
\hline & $\begin{array}{l}\text { - They found the message contradictory to page } 10 \text { because } \\
\text { if the school does not have a health professional why would } \\
\text { it have an infirmary. }\end{array}$ & $x$ & & $\begin{array}{l}\text { - Change the environment to an empty classroom. } \\
\text { - Remove the red cross from the suitcase and replace } \\
\text { it with "Diabetes Kit" as previously done. }\end{array}$ \\
\hline \multirow[t]{2}{*}{ Page 18} & $\begin{array}{l}\text { - Specify that the term "treatment" refers to the application } \\
\text { of insulin. }\end{array}$ & & $\mathrm{x}$ & $\begin{array}{l}\text { - The word treatment does not only refer to the } \\
\text { application of insulin }\end{array}$ \\
\hline & - EClarify the ideal type of treatment for high blood glucose. & & $\mathrm{x}$ & $\begin{array}{l}\text { - The sentence refers to the symptoms and not to the } \\
\text { treatment } \\
\text { - We removed the word "to go" }\end{array}$ \\
\hline
\end{tabular}

in schools, although it is difficult to apply and insufficient when related to diabetes. Therefore, studies such as this are highlighted as facilitators of the process of understanding the rights and duties of the families and schools in the context of students with diabetes, enabling communication and promoting better monitoring of these children and adolescents.

In the last few years, there was a quantitative and qualitative increase in access to technologies and the search for information in electronic publications ${ }^{(26)}$. The electronic books (e-books) carry a collection of data that may be transported and visualized in various electronic devices. They are available on the internet in different formats that may be discharged to the computer, cellphones, and tablets through downloads. Besides, they present advantages such as multiuser access, agility in technical processing, ease of portability, the permission to integrated research through links, and the facility of sharing ${ }^{(26)}$. With this information, the e-book format was satisfactory to the objective of the present study, and, thus, we defined it as the means to produce and share the educational material.

The majority of indexes of readability utilize as a basis two textual variables to determine the reading difficulty: the size of the words and the length of the sentences once that it is believed that the higher the number of syllables and the higher the length of the sentence, higher is the difficulty of reading. To facilitate the reading and the content comprehension of the e-book, all the educational sentences were individually analyzed regarding readability and apprehensibility. We previously determined the Flesch Reading Ease Index responsible for the readability of the content to better attend to the targeted audience defined by this study. Results between $50 \%$ to $75 \%$ were sufficient for a standardlevel understanding to be very easy ${ }^{(16)}$. Regarding the Coleman Liau Index, which determines the material apprehensibility, we needed to obtain a level of education around 6 to 8 years of schooling for the reading and comprehension of the text by a public with a low educational level ${ }^{(19)}$. We consider such results adequate because it confirms the necessity of readers to have attended, at least, the $4^{\text {th }}$ grade ${ }^{(19)}$.

It is unquestionable the importance of the image for a better understanding of the written message. The illustration has as main roles: attract the reader, awake and keep the interest for the reading, complement and reinforce text information. In fact, the layout and designer made the material more attractive and easier to read ${ }^{(27)}$.

To understand the expectations and the needs of your public, which, certainly, presents knowledge and different interests from 
the author, we need to be open to critique and changes. At this moment, the author realizes the lack of some content, the noncomprehension of the message, the gap between what is written and the way it can be understood, or how it is, in fact, understood by the targeted audience and the need for changes ${ }^{(16)}$.

For the e-book validation, we had to carry out the judges and targeted audience evaluation. Although the average CVC (0.97) indicated a high index of agreement among judges, and even with the high public acceptance, we still received improvement suggestions for the material. In the meetings with experts carried out after the evaluation, we confirmed if the suggestions were relevant and if we would change the e-book, which characterized its process of cultural adaptation.

We highlight the methodological rigor utilized in every step of this research, adopting consolidated criteria by recent studies ${ }^{(28-30)}$, aiming to outreach a fundamental content approach about the theme and the readability to the targeted audience. Overall, the targeted audience evaluated the e-book positively in the face of the possibility of having a material developed to help the communication between parents and school, which certainly will contribute to better education of the student with diabetes. Thus, the evaluations of the committee of judges, experts, and targeted audience demonstrated that the e-book is an educative instrument of great utility given the pertinent and valid content regarding its objective.

After concluding the elaboration, validation, and cultural adaptation of the educational e-book, the study does not end with it because not only the scientific content renews itself, as well as the Brazilian legislations may suffer changes or new laws may be created, which, consequently, creates the necessity of updating the material.

\section{Study limitations}

Although the e-book presented positive characteristics, excellent content, and innumerous advantages, as a means of dissemination it presents peculiarities that limit our work. In Brazil, there still exist places without access to the internet, thus, the access to technology is precarious or inexistent, reducing the material outreach and dissemination of the educational content.

\section{Contributions to the field}

The use of the e-book by educators and students' families may provide knowledge regarding the legislation about diabetes in schools, facilitate communication and, consequently, subsidize better monitoring of students with diabetes.

\section{CONCLUSIONS}

The e-book was elaborated and validated regarding its content and relevance. The proposal of offering information about the laws concerning diabetes in schools presented practical and scientific relevance, and it has the potential to contribute to a more adequate approach to the theme. We believe that the ebook is, besides educational material, an instrument to improve the relationship between parents and guardians of students with diabetes and education institutions.

\section{REFERENCES}

1. Baade RTW, Bueno E. Coconstrução da autonomia do cuidado da pessoa com diabetes. Interface (Botucatu). 2016;20(59):941-51. https:// doi.org/10.1590/1807-57622015.0130

2. American Diabetes Association. Classification and diagnosis of diabetes. Diabetes Care. 2018;41(suppl 1):S13-27. https://doi.org/10.2337/ dc18-S002

3. International Diabetes Federation. IDF diabetes atlas [Internet]. Brussels: Belgium; 2017. [cited 2017 Nov 23]. Available from: http://www. diabetesatlas.org

4. Oliveira JEP, Montenegro Junior RM, Vencio. Diretrizes da Sociedade Brasileira de Diabetes 2017-2018. São Paulo: Editora Clannad; 2017 [cited 2018 fev 15]. Available from: https://www.diabetes.org.br/profissionais/images/2017/diretrizes/diretrizes-sbd-2017-2018.pdf

5. Bechara GM, Castelo Branco F, Rodrigues AL, Chinnici D Chaney D, Calliari LEP, et al. "KiDS and diabetes in schools" project: experience with an international educational intervention among parents and school professionals. Pediatr Diabetes. 2018;19(4):756-60. https://doi.org/10.1111/ pedi.12647

6. Garcia LRS, Araújo TDVG, Silva PGO, Medeiros HGS, Barros SS, Garcia LCS. Knowledge of diabetes mellitus among public school professionals. Rev Bras Promoc Saude. 2017;30(1):57-63. https://doi.org/10.5020/18061230.2017.p57

7. American Diabetes Association. Children and adolescents: standards of medical care in diabetes-2020. Diabetes Care. 2020;43(Suppl 1):S163-82. https://doi.org/10.2337/dc20-S013

8. Dixe MACR, Gordo CMGO, Catarino HBP, Kraus T, Menino EPSG. Effects of an education program on knowledge and self-perception of school personnel in preparing to care for type 1 diabetes students. Einstein (São Paulo). 2020;18:eAO5101. https://doi.org/10.31744/ einstein_journal/2020ao5101

9. Jacskon CC, Albanese-O'Neill A, Butler KL, Chiang JL, Deeb LC, Hathaway K, et al. Diabetes care in the school setting: a position statement of the American Diabetes Association. Diabetes Care. 2015;38(10):1958-63. https://doi.org/10.2337/dc15-1418

10. Ministério da Saúde (BR). Resolução n 466, de 12 de dezembro de 2012 [Internet]. Brasília, DF: MS; 2013 [cited 2018 Jul 06]. Available from: https://www.jusbrasil.com.br/diarios/55483054/dou-secao-1-13-06-2013-pg-2

11. Congresso Nacional (BR). Constituição da República Federativa do Brasil: 1988. Brasília, DF: Centro Gráfico; 1988 [cited 2018 Jul 06]. Available from: http://www.planalto.gov.br/ccivil_03/constituicao/constituicao.htm 
12. Congresso Federal (BR). Estatuto da criança e do adolescente: lei $n^{\circ} 8.069$, de 13 de julho de 1990 e legislação correlata [Internet]. $16 a$ ed. Brasília, DF: Edições Câmara; 2017[cited 2018 Feb 17]. Available from: https://central3.to.gov.br/arquivo/407632/

13. Congresso Federal (BR). Brasil. Lei de diretrizes e bases da educação nacional: lei no 9.394, de 20 de dezembro de 1996 [Internet]. $14 a$ ed. Brasília, DF: Edições Câmara; 2017[cited 2018 Feb 17]. Available from: https://bd.camara.leg.br/bd/handle/bdcamara/19339

14. Congresso Federal (BR). Código de defesa do consumidor: lei n 8.078 , de 11 de setembro de 1990 e legislação correlata [Internet]. 9a ed. Brasília, DF: Edições Câmara; 2016[cited 2017 Feb 19]. Available from: https://www2.senado.leg.br/bdsf/bitstream/handle/ id/496457/000970346.pdf

15. Pasquali L. Psicometria: teoria e aplicações. Brasília, DF: UnB; 1997.

16. Lyra DH, Amaral CLF. Apreensibilidade e legibilidade de artigos científicos de um periódico nacional. Tekhne Logos. 2012;3(3):91-101.

17. Flesch RF. How to write a plain English. New York, NY: Harper and Row; 1979.

18. Kincaid JP, Fishburne RP Jr, Rogers, RL, Chisson BS. Derivation of new readability formulas (automated readability index, fog count and flesch reading ease formula) for Navy enlisted personnel. Millington (TN): Institute for Simulation and Training; 1975 [cited 2017 Feb 19]. Available from: https://stars.library.ucf.edu/istlibrary/56

19. Coleman M, Liau TL. A computer readability formula designed for machine scoring. J Appl Psychol. 1975;60(2):283-4. https://doi. org/10.1037/h0076540

20. Rubio DM, Berg-Weger M, Tebb SS, Lee S, Rauch S. Objectifying content validity: conducting a content validity study in social work research. Soc Work Res. 2003;27(2):94-105. https://doi.org/10.1093/swr/27.2.94

21. Moreira MF, Silva MIT. Legibilidade do material educativo escrito para pacientes com diabetes. Online Braz J Nurs. 2005;4(2):3-12. https://doi. org/10.17665/1676-4285.20054852

22. Hernández-Nieto RA. Contributions to statistical analysis. Mérida: Universidad de Los Andes; 2002.

23. Silva ELO. Métodos de elaboração de materiais de educação em saúde para adultos: revisão integrativa. Saude Tecnol. 2020;21:60-7. https:// doi.org/10.25758/set.2222

24. Congresso Federal (BR). Código civil: no 10.406, de 12 de janeiro de 2002 [Internet]. 9a ed. Brasília, DF: Edições Câmara; 2016[cited 2017 Feb 12]. Série legislação: no 243. Available from: http://livraria.camara.leg.br/codigo-civil.html

25. Congresso Federal (BR). Código penal: decreto-lei $n^{\circ}$ 2.848, de 07 de dezembro de 1940 [Internet]. Rio de Janeiro, DF; 1940 [cited 2017 Feb 19]. Available from: http://www.planalto.gov.br/ccivil_03/decreto-lei/del2848compilado.htm

26. Duarte ABS, Lopes AQ. Livro eletrônico e sua utilização por alunos de graduação de uma universidade federal. Inf Inf. 2015;20(3):377-409. https://doi.org/10.5433/1981-8920.2015v20n3p377

27. Moreira MF, Nóbrega MML, Silva MIT. Comunicação escrita: contribuição para elaboração de material educativo em saúde. Rev Bras Enferm. 2003;56(2):184-8. https://doi.org/10.1590/S0034-71672003000200015

28. Rodrigues LN, Santos AS, Gomes PPS, Silva WCP, Chaves EDC. Construction and validation of an educational booklet on care for children with gastrostomy. Rev Bras Enferm. 2020;73(3):e20190108. https://doi.org/10.1590/0034-7167-2019-0108

29. Lima ACMACC, Bezerra KC, Sousa DMN, Rocha JF, Oriá MOB. Construção e validação de cartilha para prevenção da transmissão vertical do HIV. Acta Paul Enferm. 2017;30(2):181-9. https://doi.org/10.1590/1982-0194201700028

30. Ribeiro SA, Moreira AD, Reis JS, Soares AN, Géa-Horta T. Elaboration and validation of a booklet on diabetes for Community Health Workers. Rev Bras Enferm. 2020;73(4):e20180899. https://doi.org/10.1590/0034-7167-2018-0899 